\title{
アンケート調査に基づく病院の地震被害と震度との関係 RELATIONSHIP BETWEEN DAMAGES OF HOSPITAL FACILITIES AND SEISMIC INTENSITY BASED ON QUESTIONNAIRE SURVEY
}

\author{
郭 耕, 杖*, 林 康 裕**, 神 原 浩*** \\ Keng-Chang KUO, Yasuhiro HAYASHI and Hiroshi KAMBARA
}

\begin{abstract}
To examine the relation between seismic intensity(JMA) and hospitals' damages, composed of interruption of medical functions, daily life functions, equipment as well as building damages including nonstructural elements, questionnaire surveys were conducted for the 2003 Off Miyagi Prefecture Earthquake, the 2003 Northern Miyagi Prefecture Earthquake and the 2003 Tokachi-oki Earthquake. Hospitals near the earthquake observation stations were selected for the surveys. Meanwhile, to compare damages of hospitals with those in other common facilities, many public facilities, such as ward offices and schools, were also investigated. Results are concluded as follows. a) Damage ratios of many building damages of hospitals are higher than common facilities, and increase with older hospitals built before 1980. b) Many building damages begin to take place at a seismic intensity 5+, and increase rapidly over seismic intensity 6. c) Damages of many equipment items related to daily life functions begin to take place at a seismic intensity 6. d) Many medical instruments show no physical damages till seismic intensity $5+$, but some may be unable to perform normally as early as at a seismic intensity 4 due to interruption of daily life functions. e) Interruption of most medical functions starts at a seismic intensity 6.
\end{abstract}

Keywords: Questionnaire survey, Hospitals, Seismic intensity, Medical functions, Nonstructural elements, Damage ratio アンケート調查, 病院, 震度, 医療機能, 非構造部材, 被害率

1 はじめに

地震災害時において病院が救命救急活動を赛施する重要な拠点施 設になることは言うまでもない。しかし、1994 年ノースリッジ地 震 ${ }^{1)} 、 1995$ 年兵庫県南部地震 ${ }^{2,3)} 、 1999$ 年台湾集集地震 ${ }^{4)}$ で、災害 拠点として機能することが期待されていた病院が充分な医療機能を 発揮できたとは言い難い。これらの震災時には、構造的な被害が大 きくなかったにもかかわらず、ライフラインの停止、非構造部材や 設備、医療機器などの被害・不具合により病院施設の開鎖や医療活 動の縮小・停止を余儀なくされた、という事例が多く見られる。即 ち、病院の機能維持を考える上で、構造だけでなく非構造部材・設 備などの耐震性を含めて考える必要がある。

実地震被害に基づいて評価された建物被害率と地震動強さとの 関倸は、都市震災予測や建物の耐震性能を統計的に評価する上で有 用である。兵庫県南部地震の後、多くの建物が甚大な被害を被った ことから, 主に構造的な被害と地震動強さとの関係について多くの

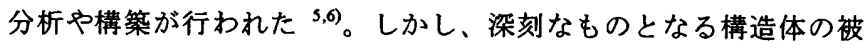
害が大きかったため、非構造部材の被害はあまり着目されておらず、 地震動強さと対応づけて分析している研究は少ない。一方、地震直 後に、医療機能を維持するために医療スタッフの対応や情報連絡な どソフト面は不可欠であるが、医療スタッフの活動を支える建物や
設備などハード面の地震被害による機能低下の度合いを、医療供給 能力の推定モデルに組み入れる必要が指摘される 7)。しかし、病院 における医療機能の支障や建物の被害・不具合がどの程度の地震動

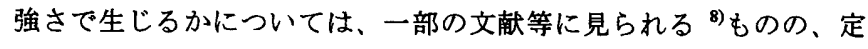
量的な評価は殆ど行われていない。

そこで、本研究では、2003 年宮城県沖の地震、宮城県北部の地 震及び十勝沖地震における病院の被害状況について、アンケート調 查を実施し、機能、非構造部材や設備を含める病院被害と地震動強 さとの関係について定量的な評価を行う。ここで、地震動強さの評 価精度をできる限り確保するために、兵庫県南部地震後に高密度配 備された地震観測網(K-NET, KiK-net, 気象庁震度観測網)の観測点 周辺の建物を対象として、アンケート調查から明らかとなった被害 を最㟢りの観測点震度階と対応付けている。また、病院施設建物固 有の地震被害傾向の有無について検討するため、病院と学校や庁舎 等その他の一般施設建物とで被害率を比較する。

\section{2 アンケートによる建物被害調査 \\ 2-1 アンケート調査の方法}

宮城県沖の地震、宮城県北部の地震及び十勝沖地震で震度 4 以 上を記録した地域の病院と一般施設の被害状況を調查するために、
* 京都大学大学院工学研究科 博士後期課程 - 工修

** 京都大学防災研究所 助教授・工博

*** 清水建設侏技術研究所工修
Graduate Student, Graduate School of Engineering, Kyoto University, M. Eng. Assoc. Prof., Disaster Prevention Research Institute, Kyoto Univ., Dr. Eng. Institute of Technology, Shimizu Corporation, M. Eng. 
地震後一ヶ月頃に郵送によるアンケートを寒施した。調査対象とし た施設は、病院については病床を有する医療施設とし、一般施設に ついては住宅を除いた庁舎、学校などの公共施設とした。また、地 震動強さと関係づけるために、一般施設については、地震観測網 (K-NET, KiK-net，気象庁震度観測網)の観測点からおおよそ $500 \mathrm{~m}$ 以 内にある建物を対象とした。病院施設については、サンプル数を確 保するために、一般施設よりも広範囲にある施設を調查対象とし、 最寄りの観測点の地震動強さを参照した。3 度の地震において、病 院 323、一般施設 363 にアンケート用紙を送付した。1 施設から複 数の建物について回答が得られたものもあり、回答が得られた建物 棟数は、病院 228 棟、一般施設 267 棟であった。

調査で用いたアンケート用紙には、建築年代、構造種別、規模な どの建物基本情報に関する質問と、地震による被害に関する質問を 設け、被害に関する質問では、非構造部材を含む建物の外部・内部、 生活機能と設備、医療機能（病院施設のみ）の3つに分けて、それ ぞれ表 1 に示す被害項目に対して、地震による被害・不具合の有無 を図 1 に示すように「なし」「あり」「多数」を選択する形式で回答 してもらった。このとき、被害が 1 筒所のときは「あり」を、被害 が 2 箇所以上のときは「多数」を選択してもらうようにした。また、 医療機器や設備に関する質問では、機器や設備がない場合に「該当 なし」を選択してもらうようにした。

\section{2-2 回答が得られた建物の概要}

アンケートの回答が得られた建物の概要について図 2 に示す。建 物の構造種別は、病院施設の約 9 割が RC 造であったため、RC 造 建物のみについて被害を分析した。震度別の棟数比率は、病院、一 般施設ともにほぼ同程度で、震度 4 で $40 \%$ 、震度 5 で $50 \%$ 、震度 6 で 10\%となっている(図 2(a))。建築年代について、1981 年以後の棟 数比率は病院で $50 \%$ 、一般施設で 35\%(図 2(b))、病院より一般施設 の方が古い建物の棟数比率がやや高い。なお、病院建物は增改築が 行われている場合には一番古い建築年代を採用した ${ }^{9}$ 。建物規模で は病院、一般施設とも 6 階以下の中低層建物が殆どである。特に、 一般施設では 3 階建て以下の低層建物が 8 割を占めている(図 2(c))。 また、何らかの被害や不具合があった建物の割合は、病院で 6 割、

一般施設で 4 割である(図 2(d))。病院の方が一般施設より 2 割程度 高くなっている。

\section{3 建物の被害}

建物の被害については、空ガラス、天井など非構造部材も含め、 本研究では主として建筑物の部位ごとに調查している。まず、建築 年代や地震動強さで区分しない平均的被害率が高かった項目を一般 施設と比較して図 3 に示す。ここでは、被害が「なし」、「あり小、 「多数」のいずれかを回答した棟数に対する「あり」または「多 数」を回答した棟数の比を被害率とした。図 3(a)から病院で被害率 が高かったのは、外壁ひび割れと机上物転倒がそれぞれ約 $20 \%$ と 約 $25 \%$ であり、次いで、家具転倒、ガラス製品破損が $15 \%$ 前後、 外壁はがれ、床ひび割れ、空ガラスひび、天井ずれが 10\%程度で ある。多くの項目で病院での被害率は一般施設より高くなっている ことが分かる。ただし、建築年代別で見ると(図 3(b),(c))、病院にお ける家具転倒やガラス製品破損など室内の家具・什器の被害では、 建築年代による被害率の差は小さかった。一方、外壁、天井、床や
表 1 アンケートに設けられた被害項目

\begin{tabular}{|c|c|c|}
\hline 項 & 目 & 内 \\
\hline \multirow{3}{*}{ 外 } & 柱、壁 & $\begin{array}{l}\text { コンクリートや仕上材のひび割れ/はがれ } \\
\text { /鉄筋露出 }\end{array}$ \\
\hline & 空ガラス & $\begin{array}{l}\text { ガラスのひび/割れ, サッシの装形, } \\
\text { 空の開閉困難/開閉不能 } \\
\end{array}$ \\
\hline & 出入口 & $\begin{array}{l}\text { 屝の変形/はずれ, ガラス割れ, } \\
\text { 屝の開閉困難/開閉不能 }\end{array}$ \\
\hline \multirow{5}{*}{ 建物 } & 柱、壁 & $\begin{array}{l}\text { コンクリートや仕上材のひび割れ/はがれ } \\
\text { /鉄筋露出 }\end{array}$ \\
\hline & 屝 & $\begin{array}{l}\text { 屝の変形/はずれ，ガラス割れ， } \\
\text { 屝の開閉困難/䦩閉不能 } \\
\end{array}$ \\
\hline & 天井 & 天井板のずれ/落下 \\
\hline & 床 & ひび割れ/タイルはがれ \\
\hline & 室内の家具 ·什器 & $\begin{array}{l}\text { 机の移動, 机上物の転倒, 家具の移動/ } \\
\text { 転倒, テレビの転倒, ガラス製品の破損 }\end{array}$ \\
\hline \multirow{7}{*}{ 生活機能と設備 } & 生活機能の供給 & $\begin{array}{l}\text { 電気、水、ガス、空調, 洗濯施設, 給食 } \\
\text { 施設 }\end{array}$ \\
\hline & 電気設備 & 照明のずれ/破損, 照明落下 \\
\hline & 給排水設備 & $\begin{array}{l}\text { 洗面台破損，トイレ使用不能，便器破損, } \\
\text { 壁タイルばれ，配管破損 } \\
\end{array}$ \\
\hline & 空調設備 & $\begin{array}{l}\text { 空調機の故障，吹出口破損， } \\
\text { 配管破損，室外機転到 }\end{array}$ \\
\hline & 屋上の設備機器 & $\begin{array}{l}\text { 空瞏機の移動/転倒, 高架水槽の破損/転 } \\
\text { 到, 配管のはずれ }\end{array}$ \\
\hline & 防災設備 & $\begin{array}{l}\text { スプリンクラーの破損/買作動, } \\
\text { 防火罪の開閒困難，防煙垂れ壁の破損 } \\
\end{array}$ \\
\hline & 輸送設備 & エレベータの自動停止/故障 \\
\hline \multirow{4}{*}{ 医療機能 } & 医療空間の使用 & $\begin{array}{l}\text { 病室, 診療室, 検查室, } \\
\text { 手術室, 調珮室, 材料室 }\end{array}$ \\
\hline & 検査機器 & $\begin{array}{l}\text { X線透視装置, フィ似現像機, } \\
\text { 血液検查機, CT, MRI，アソギオ }\end{array}$ \\
\hline & 治療 · 処置機器 & $\begin{array}{l}\text { 傷の洗浄, 器具の煮沸・消毒, 生命維持 } \\
\text { 装固, 人工透析, 一般治療, 手術実施 } \\
\end{array}$ \\
\hline & 投楽とその他 & $\begin{array}{l}\text { 自動分包機，医薬品や診療材料, } \\
\forall-x I-N \text {, th厂二作成 }\end{array}$ \\
\hline
\end{tabular}

質問 2-1 建物外部の被害·不具合について

(1) 柱

・コンクリートや仕上材にひび割れが生じた。

口なし ちあり口多数（１）階口補修 ・コンクリートや仕上材がはがれた。

あなし 口あり口多数( 階 口補修 ....

質問 2-2 建物内部の被害·不具合について

....

(4) 天井

・天井板がずれた・欠けた。

口なし †おり口多数 (2,3) 階 口補修

・ 天井板が落下した。

女なしロあり口多数 (口) 階 口補修

....

質問 3-2 地震後の機能障害について

(1) 検査

・X線透視装置が使用できなかった。

口なしロあり、約( )日（）時間で復旧した ち該当なし $\cdots \cdot \cdot$

図1 アンケートの回答方法

空ガラスなど建築物の空間を構成する要素の被害では、1981 年以 後に建設された病院（新しい病院と呼ぶ）での被害率が低くなり一 


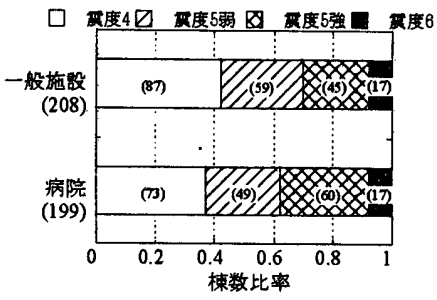

(括弧内の数字は棟数を表す)

(a) 震度別

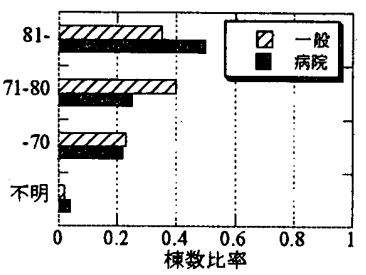

(b) 建築年代

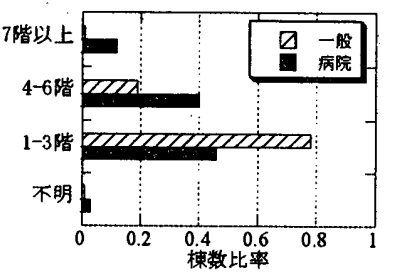

(c) 規模

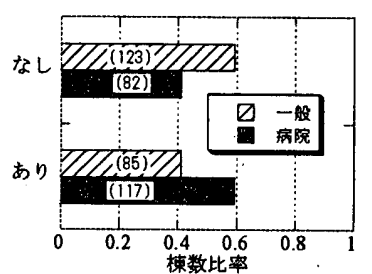

(括弧内の数字は棟数を表す)

(d) 被害・不具合の有無

図 2 アンケートの回答が得られた建物の棟数比率

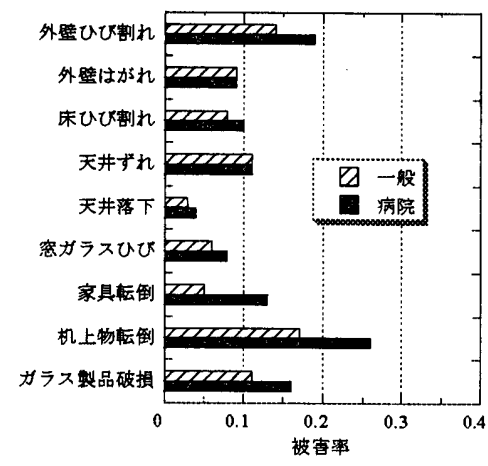

(a) 全年代

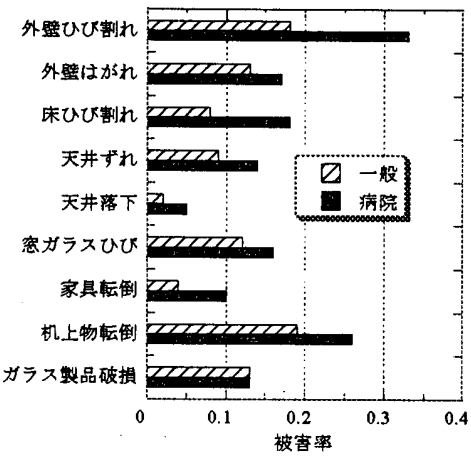

(b) 1980 年以前

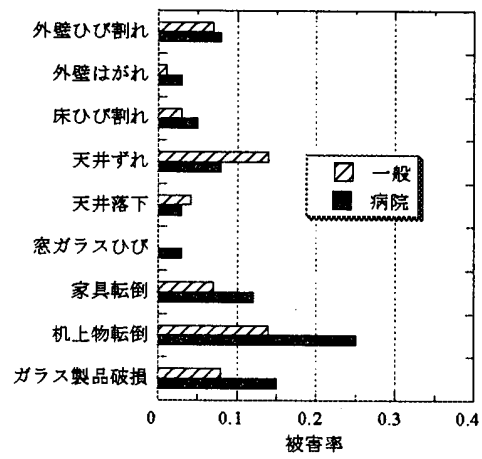

(c) 1981 年以後

図 3 病院と一般施設に発生した建物の被害の比較

般施設との差はあまりないのに対して、1980 年以前に建設された 病院（古い病院と呼ぶ）での被害率が高く一般施設より被害が発生 しや寸くなっている。

次に、観測点の震度を震度 4、5 弱、5 強、6（6 弱と 6 強）で区 分し、地震動強さの区分毎に、被害が「あり」または「多数」の割 合を被害率と計算した。また、被害率 $5 \%$ 未満，5 10\%，10\%以上を、 それぞれ被害の可能性が極めて低い、可能性が低い（一部の建物で 発生する)、可能性がある ${ }^{10)}$ と考え、アンケートに設けられた建物 の被害について建築年代を問わず可能性の高低を表 2 に示す。この 表から、病院の建物では、多くの被害は震度 5 強以上で発生する可 能性があり、外内壁と柱の被害やガラス製品破損は震度 5 弱でも一 部の建物で発生する可能性があることが分かる。アンケートに設け られた被害項目の殆どは、震度 6 で発生する可能性があることが分 かる。

外壁, 天井, 空ガラス, 家具など代表的な被害モードについて建 築年代別・震度別で被害率を比較して図 4 に示す。まず、外壁ひび 割れについては(図 4(a))、建築年代に関わらず病院での被害率は震 度 4 で約 3\%である。古い病院での被害率は、震度 5 弱で $30 \%$ に急 増し、震度 5 強で $50 \%$ 程度となっている。外壁はがれについては (図 4(b))、古い病院では震度 4 で被害が発生し始め（被害率約 3\%)、 被害率は震度 5 で $15 \%$ 程度、震度 6 では $50 \%$ を超えている。一方、 新しい病院では震度 5 弱から発生し始めるが、震度 6 まで被害率は $5 \%$ 程度にとどまっている。外壁のひび割れやはがれの被害は、震 度 5 弱以上で建築年代による被害率の差が大きくなっている。

次に、天井ずれについては、図 4(c)に示すように必ずしも震度と の相関が高くないが、震度 4 5 弱の地域では古い病院の $10 \%$ 程度 に被害が発生しているのに対して、新しい病院では殆ど発生してい ない。しかし、新しい病院の被害率は、震度 5 強以上で高くなり、
震度 6 では古い病院の被害率を上回っている。また、天井落下につ いても(図 4(d))、建築年代による被害率の差はあまりなく、新旧と もに震度 5 強まで $5 \%$ 以下になっているが震度 6 で $15 \%$ 以上に急增 している。従って、新しい病院でも天井の耐震性は十分とは言い難 い。

ガラスひびについては(図 4(e))、新しい病院では震度 6 まで被害 は殆ど発生していないが、古い病院では震度 5 弱で 15\%程度に急 増し、震度 5 の地域で一般施設より被害率が高くなり、建築年代に よる被害の傾向も異なる。これは、古い建物で用いられたガラスの 取付け方法の変形追随性が低かったためと推測される。

最後に、家具転倒については(図 4(f))、古い病院での被害率は震 度 4 で発生し始め（約 $5 \%$ )、震度 5 強までは $10 \%$ 程度にとどまっ ているが、震度 6 で 50\%を超えている。一方、新しい病院では震 度 5 弱まで $5 \%$ 以下であるが、震度 5 強で古い病院の被害率を上回 り $20 \%$ 程度に急增し、震度 6 では $40 \%$ に達している。新しい病院 と一般施設ともに震度 5 強以上で家具転倒の被害率が高くなり、古 い建物での被害率を上回る結果となっている。

これら建物の被害と震度との関係から、被害の多くは震度 5 弱か ら発生し始めている（被害率 $5 \%$ 以上）が、古い病院では震度 4 で も天井ずれや家具転倒が発生していることが分かる。また、天井や 家具の被害に比べ、外壁やガラスの被害では建築年代による被害率 の差がより顕著になっている。

\section{4 生活機能と設備の被害}

電気, 給水, ガス, 空調などの生活機能の停止については、病院 建物と一般施設のいずれにおいても、被害率が5\%以下と高くなか った。この理由として、地震動強さが大きくなかった地域の建物が 多く含まれていることが考えられる。そこで、生活機能停止の被害 
表 2 震度別の建物の被害可能性

\begin{tabular}{|c|c|c|c|c|}
\hline \multirow{2}{*}{ 被害項目 } & \multicolumn{4}{|c|}{ 震度階 } \\
\hline & 4 & 5- & $5+$ & 6 \\
\hline \multicolumn{5}{|l|}{ U. } \\
\hline \multicolumn{5}{|l|}{ 柱ひび割れ } \\
\hline \multicolumn{5}{|l|}{ 柱はがれ } \\
\hline 柱鉄筋露出 & & & & $\mathrm{O}$ \\
\hline \multicolumn{5}{|l|}{4 (4) } \\
\hline \multicolumn{5}{|l|}{ 壁ひび割れ } \\
\hline \multicolumn{5}{|l|}{ 壁はがれ } \\
\hline \multirow{2}{*}{\multicolumn{5}{|c|}{ 壁鉄筋露出 }} \\
\hline \multicolumn{3}{|l|}{ 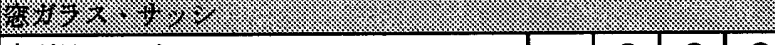 } & & \\
\hline 空ガラスひび & & 0 & 0 & O \\
\hline 空ガラス割れた & & 0 & Q & 운 \\
\hline サッシが変形した & & 0 & & 0 \\
\hline \multicolumn{5}{|l|}{ 空が開閉しにくくなった } \\
\hline 窓が開閉できなくなった & & & & 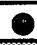 \\
\hline \multicolumn{5}{|c|}{ 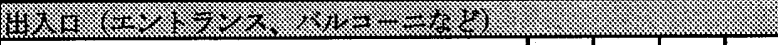 } \\
\hline 踌が変形した & & & & 0 \\
\hline \multicolumn{5}{|l|}{ 扉がはずれた } \\
\hline \multicolumn{5}{|l|}{ 屝が開閉しにくくなった } \\
\hline 屝が開閉できなくなった & & & & $\mathrm{O}$ \\
\hline \multicolumn{5}{|l|}{ (1) } \\
\hline 柱ひび割れ & & 2 & - & ? \\
\hline 柱はがれ & & & 0 & ? \\
\hline 柱鉄筋露出 & & & & 0 \\
\hline
\end{tabular}

\begin{tabular}{|c|c|c|c|c|}
\hline \multirow{2}{*}{ 被害項目 } & \multicolumn{4}{|c|}{ 震度階 } \\
\hline & 4 & $5-$ & $5+$ & 6 \\
\hline \multicolumn{5}{|l|}{ (2) } \\
\hline 壁ひび割れ & 0 & - & - & - \\
\hline 壁はがれ & & 0 & - & 은 \\
\hline 壁鉄筋露出 & & & & 0 \\
\hline \multicolumn{5}{|l|}{ les: } \\
\hline \multicolumn{5}{|l|}{ 屝が変形した } \\
\hline 屝がはずれた & & & & 0 \\
\hline 屝が開閉しにくくなった & & & 0 & 2 \\
\hline \multicolumn{5}{|l|}{ 屝が開閉できなくなった } \\
\hline \multicolumn{5}{|l|}{ 2.) } \\
\hline 天井はずれ & & 0 & - & 운 \\
\hline 天井落下 & & & 0 & e \\
\hline \multicolumn{5}{|l|}{ 1. } \\
\hline 床ひび割れ & & & 9 & 운 \\
\hline 林タイルはがれ & & & & 2 \\
\hline \multicolumn{5}{|l|}{ (5) } \\
\hline 机が移動した & & ? & 운 & 웅 \\
\hline 机上物転倒 & 0 & 0 & - & 운 \\
\hline 本棚など背の高い家具が移動した & & 0 & 운 & e \\
\hline 本棚など背の高い家具が転倒した & & 0 & e & 8 \\
\hline テレビが転倒した & & 0 & 0 & 운 \\
\hline 花瓶や食器等のガラス製品が破損した & 0 & e & - & 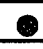 \\
\hline
\end{tabular}

空白：可能性が極めて低い（ $5 \%$ 未満） ○：可能性が低い (5 10\%)

：可能性がある(10\%以上)

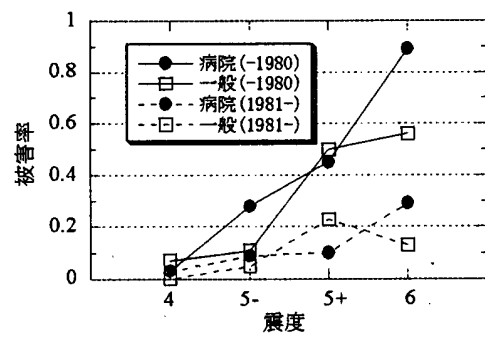

(a) 外壁ひび割れ

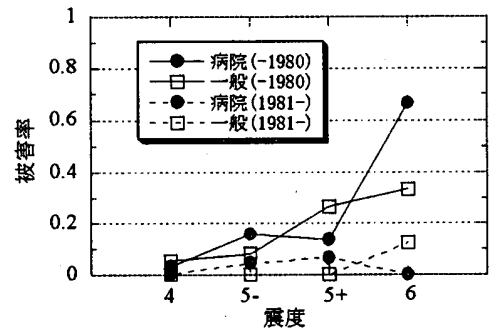

(b) 外壁はがれ

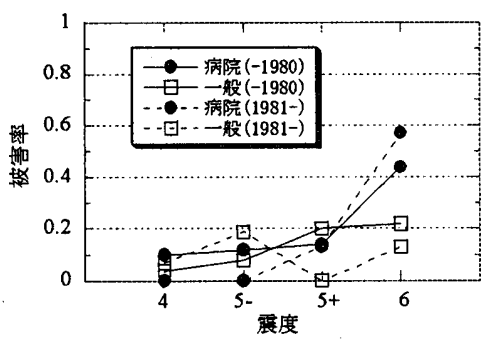

(c) 天井ずれ

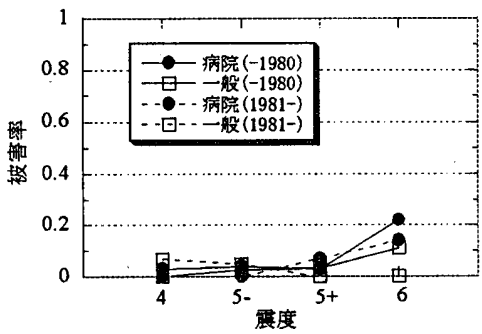

(d) 天井落下

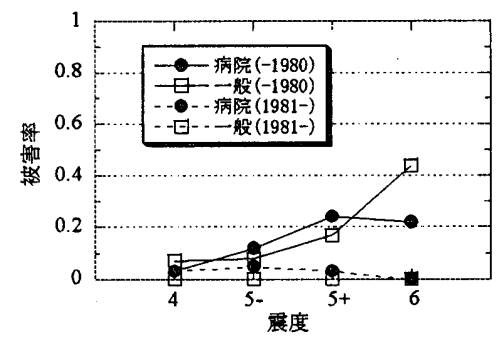

(e) 空ガラスひび

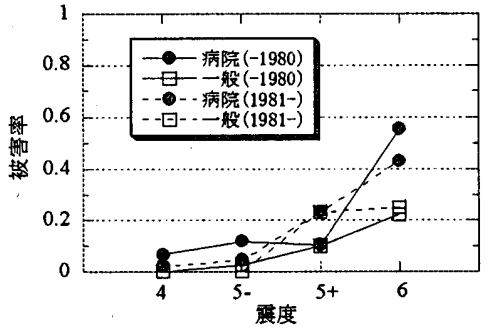

(f) 家具転倒

図 4 建物の被害と震度との関倸

率について、震度別に図 5 に示す。電気の停止は震度 6 でも被害率 は $5 \%$ 程度となっているが、給水やガスの停止は震度とともに被害 率が增大し、震度 6 では $20 \%$ 弱に達している。空調の停止は震度 5 強から発生し始めているが、震度 6 になっても被害率は $5 \%$ 程度で 大きく変わらない。給食施設の使用不能については、震度 5 強まで 被害率は $5 \%$ 以下であるが、震度 6 で $15 \%$ に急增している。洗濯施 設の使用不能については、震度 5 強まで殆ど発生していないが、震 度 6 で $20 \%$ に急增している。以上の様に、生活機能の震度別の被 害率から、殆どの機能で震度 5 強まで $5 \%$ 以下になっているが、震 度 6 になると被害率が急增することが分かる。ただし、今回調查し た建物で、電気、給水およびガス停止の被害率は震度 5 強まで $5 \%$
くらいと低かったのは、地域ライフラインの被害率がそれほど高

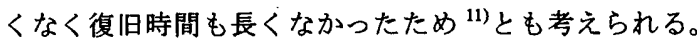

建築年代を区別せず、生活機能に関する設備の被害の可能性を表 3 に示す。この表から、配管破損水漏れは震度 5 弱で、エレベータ の自動停止は震度 4 でも発生する可能性があるが、多くの設備は震 度 6 で被害が発生する可能性があることが分かる。また、空調設備 やスプリンクラーなどの防災設備については、震度 6 まで被害が発 生する可能性は極めて低いことが分かる。

次に、給水停止に関連する設備被害の中から、配管破損水漏れと 屋上高架水槽破損に着目し、その震度別被害率を図 6 に示寸。配管 破損水漏れの被害率は震度とともに増大し、古い病院で被害率が高 

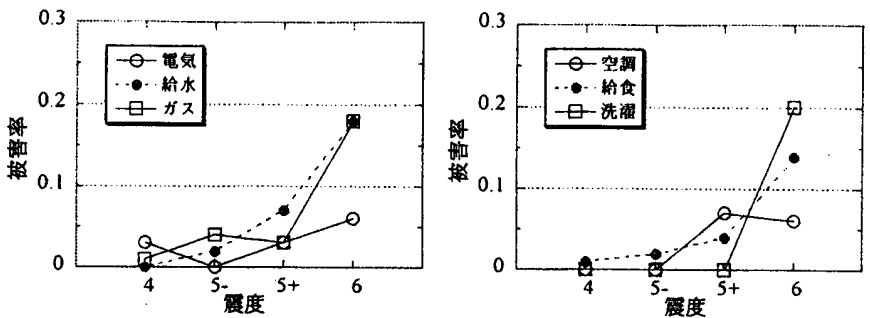

図 5 生活機能の被害と震度との関係

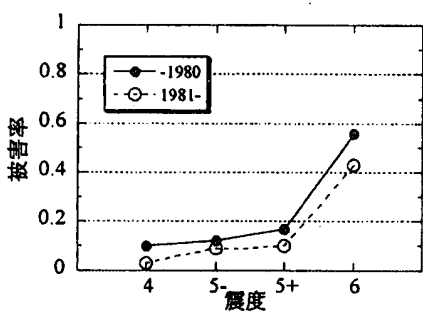

(a) 配管破損水漏れ

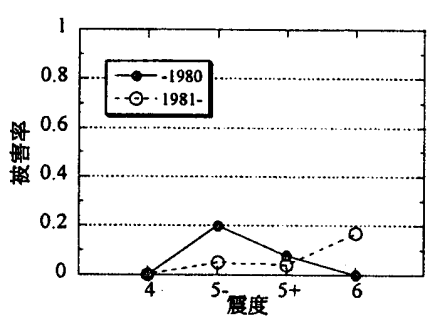

(b) 高架水槽破損
図 6 給水設備の被害と震度との関係

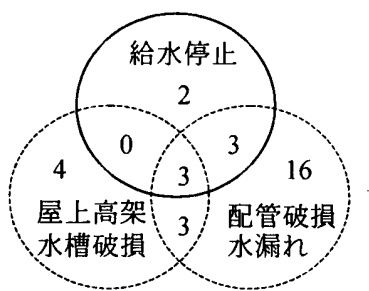

表 41980 年以前の病院における 配管破損とガラスひび割れの関係

\begin{tabular}{|c|c|c|}
\hline \multirow{2}{*}{ 被害項目 } & \multicolumn{2}{|c|}{ ガラスひひ割れ } \\
\hline & あり & なし \\
\hline 配管破損あ & $9(0.10)$ & $7(0.08)$ \\
\hline 水漏九 & $4(0.04)$ & $73(0.78)$ \\
\hline
\end{tabular}

図 7 給水停止と設備被害の関係
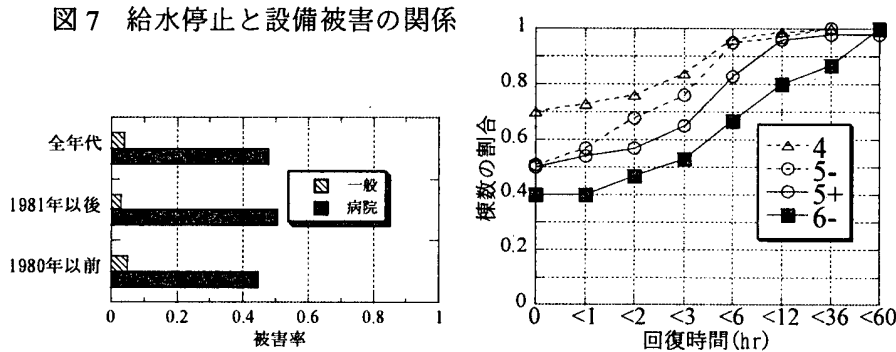

図 8 施設によるIレベ-夕停止の比較 因 9 Iレベ-夕回復時間の累積分布

くなる傾向にあるが、震度 6 で新旧ともに被害率が急增している。 しかし、屋上高架水槽破損の被害率は、震度と相関が高いとは言い 難い。一方、給水停止となった 8 件のうち、䖲水の発生した 1 件と 夜間断水した 1 件を除けば、6 件全てが配管破損(うち 3 件で高架 水槽が破損)しており(図 7)、給水停止の主要因は配管破損と考えら れる。また、配管破損 6 件のうち 5 件は 1980 年以前の病院であっ た。そこで、古い病院における配管破損を、最大層間変形角と対応 づけやすいガラスひびとの関係を表 4 に示す。配管破損が生じてい る病院では、ガラスひびも多く発生しており、配管破損も層間変形 に追随できず発生している可能性が示唆される。

最後に、日常の輸送機能に関するエレベータの使用停止について は、図 8 に示すように建築年代に関わらず一般施設より病院の被害 率が明らかに高く、50\%に達している。しかし、震度別の回復時間 をみると、図 9 に示す様に、震度 5 強以下の地域で 8 割以上、震度 6 で 7 割程度のエレベータが 6 時間以内に回復している。これは、 ガイドレールのゆがみなど機器自体が損傷したものは殆どなく、病 院において地震時エレべータを自動停止させるときの建物応答レベ ルが低かったためと推測される。
表 3 震度別の設備の被害可能性

\begin{tabular}{|c|c|c|c|c|}
\hline \multirow{2}{*}{ 被害項目 } & \multicolumn{4}{|c|}{ 震度階 } \\
\hline & 4 & $5-$ & $5+$ & 6 \\
\hline \multicolumn{5}{|c|}{ 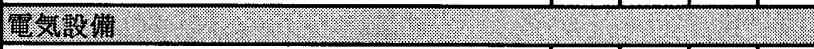 } \\
\hline 天井の照明がずれた・壊れた & & 0 & $\mathrm{O}$ & \\
\hline 天井の照明が落下した & & & $\mathrm{O}$ & \\
\hline \multicolumn{5}{|l|}{ 給排水飘䋖 } \\
\hline \multicolumn{5}{|l|}{ 洗面台が壊れた } \\
\hline \multicolumn{5}{|l|}{ トイレが使えなくなった } \\
\hline \multicolumn{5}{|l|}{ 便器が壊れた } \\
\hline ト化や洗面台の壁タイルがはがれた & & & $\bigcirc$ & \\
\hline 配管破損・水漏れが生じた & $\mathrm{O}$ & 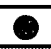 & 8 & \\
\hline \multicolumn{5}{|l|}{ 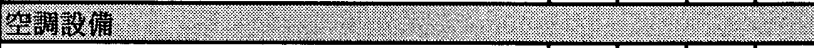 } \\
\hline \multicolumn{5}{|l|}{ 天井や壁にある空調機が壊れた } \\
\hline 天井や壁にある吹出口が壊れた & & & & 0 \\
\hline 天井などにある空調用配管が壊れた & & & 0 & $\mathrm{O}$ \\
\hline バルコニーにある室外機が転倒した & & & & $\mathrm{O}$ \\
\hline \multicolumn{5}{|l|}{ 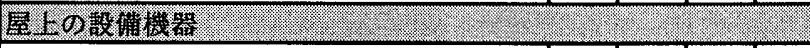 } \\
\hline 空調機が移動した & & & & $\mathrm{O}$ \\
\hline \multicolumn{5}{|l|}{ 空調機が転倒した } \\
\hline 高架水槽が破損した & & - & 0 & 0 \\
\hline \multicolumn{5}{|l|}{ 高架水槽が転倒した } \\
\hline 配管がはずれた & & 0 & - & 0 \\
\hline \multicolumn{5}{|l|}{ 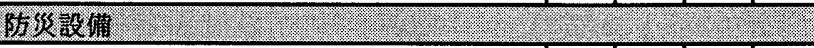 } \\
\hline スプリンクラーが破損した & & & & $\mathrm{O}$ \\
\hline \multicolumn{5}{|l|}{ スプリンクラーが誤作動した } \\
\hline 防火屝が開閉しにくくなった & & & $\mathrm{O}$ & \\
\hline 防煙垂れ壁が破損した & & & & $\bigcirc$ \\
\hline \multicolumn{5}{|l|}{ 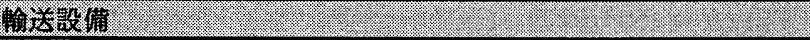 } \\
\hline Iレベータが自動停止 & 20 & 0 & 8 & 0 \\
\hline Iレベータが壊れた（動かなくなった） & & $\mathrm{O}$ & $\mathrm{O}$ & 2 \\
\hline $\begin{array}{l}\text { 停電になったが非常用電源(発電装置)が稼 } \\
\text { 暄しかった }\end{array}$ & & & & \\
\hline
\end{tabular}

空白：可能性が極めて低い（5\%末満）

○：可能性が低い $(5 \sim 10 \%)$ ○: 可能性がある（10\%以上）

\section{5 医療機能の被害}

医療機能については、一般に、地震後の災害医療に関する医療機 器と医療空間に分けられる。ここでは、医療機器を検査、治療・処 置、投薬、その他（ナースコールの使用，カルテ作成など）に分類 ${ }^{8)}$ し、医療空間を病室, 診療室, 検查室, 手術室, 調剤室, 材料室に

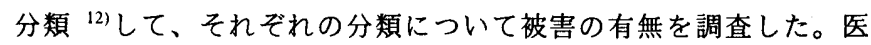
療機器と医療空間の使用不能については、いずれも平均的被害率は $5 \%$ 以下と高くなかった。この理由として、今回の調査で医療機能 の支障を大きく及ぼすライフラインや建築設備の被害率が高くなか ったことも考えられる。

次に、検査、治療・処置など医療機器の震度別被害率を図 10 お よび図 11 に示す。震度 6 では多くの医療機器の被害率が急增して いるが、医療機器については震度 5 強までは概ね機能維持ができて おり、被害率は $5 \%$ 前後である。なお、図 10 において、震度 4 の 検查機器の被害は停電によるものであり、震度 5 強の CT 使用不能 は高架水槽破損による水浸によるものである。即ち、X 線透視装置、 血液検査機、CT、MRI の物理的な被害は、震度 5 強までは殆ど発 生していないと考えられる。

また、医療空間が使用不能となった被害率を図 12 に示す。構造 的な被害が見られた震度 6 地域の病院（公立深谷病院、鹿島台国保 病院）で医療空間は使用不能となっているが、震度 5 強までは概ね 

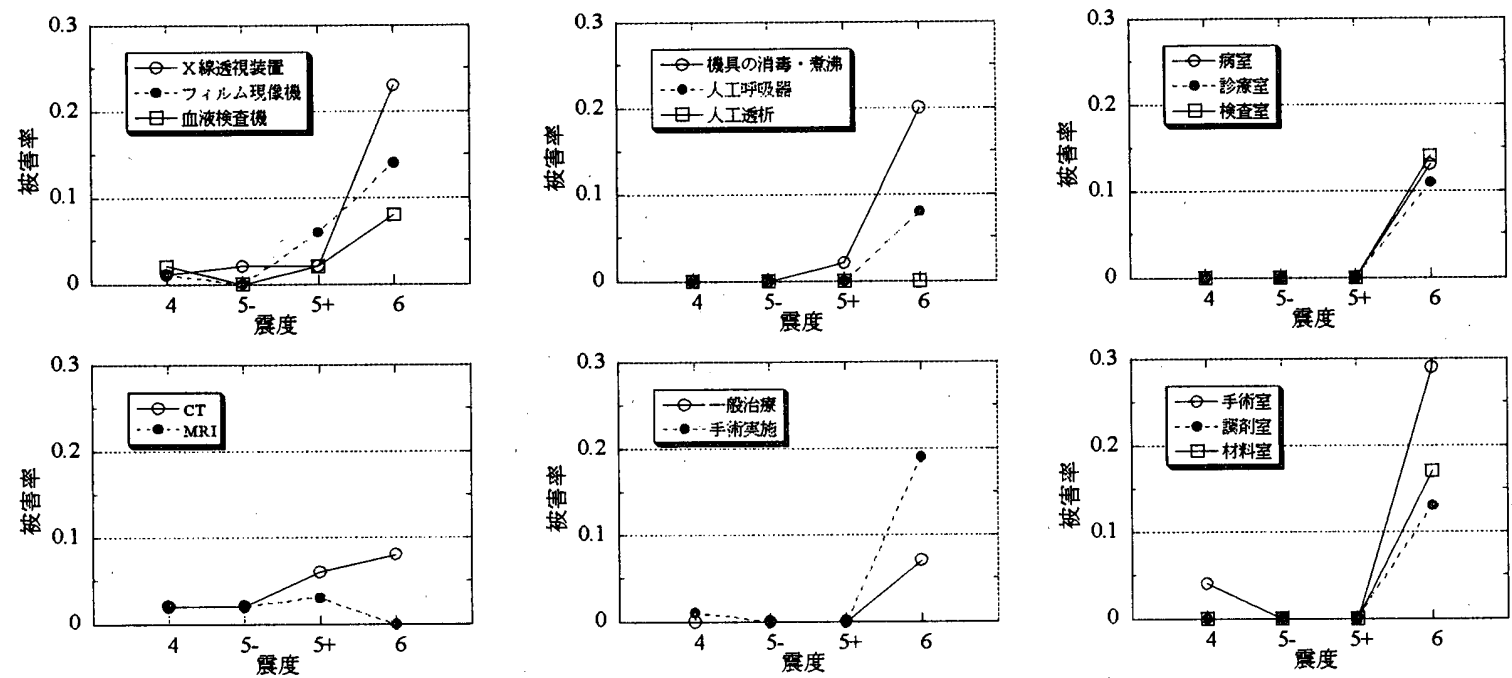

図 10 医療検査機器の被害と震度との関倸

図 11 医療治療・処置機器の被害と震度との関係

図 12 医療空間の被害と震度との関係

表 5 震度別の医療機能の被害可能性

\begin{tabular}{|c|c|c|c|c|}
\hline \multirow{2}{*}{ 被害項目 } & \multicolumn{4}{|c|}{ 震度階 } \\
\hline & 4 & 5- & $5+$ & 6 \\
\hline \multicolumn{5}{|l|}{64} \\
\hline \multicolumn{5}{|l|}{ X線透視装置が使用できなかった } \\
\hline フイルムが使用できなかった & & & 0. & 2 \\
\hline 血液検查機が使用できなかった & & & & $\mathrm{O}$ \\
\hline CTが使用できなかった & & & 0 & 0 \\
\hline \multicolumn{5}{|l|}{ MRIが使用できなかった } \\
\hline アソギオや心臓力テーテルなどが使用できなかった & & & & 0 \\
\hline \multicolumn{5}{|l|}{ Whe } \\
\hline \multicolumn{5}{|l|}{ 器具の煮沸・消冨ができなかった } \\
\hline 生命維持装置が使用できなかった & & & & 0 \\
\hline \multicolumn{5}{|l|}{ 人工透析ができなかった } \\
\hline 一般治療ができなかった & & & & 0 \\
\hline 手術が寒施できなかった & & & & 9 \\
\hline \multicolumn{5}{|l|}{ (6) } \\
\hline 自動分包機が使用できなかった & & & & $\mathrm{O}$ \\
\hline \multicolumn{5}{|l|}{$\begin{array}{l}\text { 医薬品や診療材料が使用できなかった(例え } \\
\text { ば浸水のため) }\end{array}$} \\
\hline \multicolumn{5}{|l|}{ ナースコールが使用できなかった } \\
\hline \multicolumn{5}{|l|}{ 咖テ作成ができなかった } \\
\hline \multicolumn{5}{|l|}{ 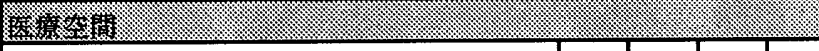 } \\
\hline \multicolumn{5}{|l|}{ 病室が使用できなかった } \\
\hline \multicolumn{5}{|l|}{ 診療室が使用できなかった } \\
\hline \multicolumn{5}{|l|}{ 検查室が使用できなかった } \\
\hline \multicolumn{5}{|l|}{ 手術室が使用できなかった } \\
\hline \multicolumn{5}{|l|}{ 調剤室が使用できなかった } \\
\hline 材料室が使用できなかった & & & & 2 \\
\hline
\end{tabular}

使用できている。医療機器及び医療空間の使用不能ともに、被害率 は震度 5 强まで $5 \%$ 以下で、震度 6 から急増している傾向が見られ る。

最後に、建築年代を問わず医療機能の被害の発生可能性を表 5 に 示す。この表から、医療機能の多くは震度 6 以上で被害が発生する 可能性があることが分かる。診療材料やナースコールの使用不能、 カルテ作成不能は、震度 6 でも被害が発生する可能性は極めて低く なっている。
6 まとめ

本研究では、2003 年宮城県沖の地震、宮城県北部の地震及び十 勝沖地震における病院の被害状況についてアンケート調查を実施し、 機能、非構造部材や設備を含めた病院被害と地震動強さとの関係に ついて定量的な評価を行った。また、病院施設固有の地震被害傾向 についても検討するため、被害率と地震動強さとの関係を病院以外 の学校や庁舎等の一般施設と比較した。その結果、震度 6 以下の地 域における建物の外部・内部、生活機能と設備、医療機能の被害に ついて次のことが明らかとなった。

・病院は一般施設よりも建物被害発生しやすく、特に古い病院での 被害率が高い。また、室内の家具・什器の転倒・散乱被害は、 新・旧病院の被害率に顕著な差は見られなかった。

・病院の建物被害の多くは、震度 5 強から発生する可能性があり (被害率 $10 \%$ 以上)、震度 6 で急增する傾向にあるが、震度 5 弱以 下の地域でも外内壁と柱のひびや机上物転倒、ガラス製品破損が 発生している。

・生活機能に関する設備の多くは、被害が震度 6 より発生している が、配管破損水漏れやエレベータの自動停止は震度 5 弱以下でも 生じている。

・給水停止を及ぼす設備被害原因として、高架水槽の破損よりもむ しろ建物の変形追随困難な古い配管の破損の可能性が示唆された。 ・多くの医療機器は、震度 5 強以下では物理的に損傷していない。 ケースは少ないが、電気停止など生活機能の被害や設備被害など により、震度 4 程度から機能喪失する場合もある。

・医療機器、医療空間ともに、震度 5 強まで機能は概ね維持でき、

震度 6 から使用不能の発生する可能性がある。

病院に関する非構造部材、設備や機能まで含めて被害と震度との関 係を系統的に分析した事例はこれまでにない。本研究で得られた結 果は、地震時に防災拠点としての既存病院の耐震性を把握する上で 有用であると考えられる。ただし、今回の調査で得られた震度 6 の 事例数は十分でなく、精度を上げるためにも今後データの更なる蓄 積が必要である。 


\section{铸辞}

本研究では、地震動强さは、気象庁、防災科学技術研究所（K-NET および KiK-net）で公開されている顊测記録を利用して算出しました。関係各位に 御礼を申し上げます。また、アンケートに回答して頂いた皆様に御礼を申し 上げます。

\section{参考文献}

1) William T. Holmes, et al., "Northridge Earthquake of January 17, 1994 Reconnaissance Report", Vol. 2, pp.229-231, Earthquake Spectra, USA, 1994

2）日本医療福祉建筑協会: 兵庫県南部地震病院被災調查報告書, 1996.3

3）小虽鐸二研究所：1995 年兵庫県南部地震医療機関とその敕急医療活動 に関する調查報告一被災時における闑き取り調查一、1995.4

4）台湾国家地震工程研究中心：1999 年9月21日台湾中部集集地震災害調 查速報(二), pp.147-150, NCREE-99-031, 1999.11(中国語)

5）村尾修，山崎文雄：自治体の被害調査結果に基づく兵庫県南部地震の建 物被害関数, 日本建策学会構造系論文集, No.527, pp.189-195, 2000.1

6) 林康裕, 宫腰淳一：兵庫県南部地震による被害率曲線，建筑学会災害部 阿 PD 資料, pp. 15-20, 1998
7) 今泉恭一, 佐藤博臣, 室崎益輝：病院の患者受け入れ能力に関する推定 モデルの検討一震災時・医療制約の定量的評価に関する研究一，日本建 築学会計画系踚文集, No.509, pp.157-163, 1998.7

8) 村田明子：地震後の病院の機能障曋とリスク晾断, 日本建築学会大会学 術講演梗概集, pp.1101-1102, Vol.E-1, 2001.9

9）日本建築学会 : 阪神淡路大震災調查報告 建策編-1 鉄筋コンクリート造 建筑物，第 I 編 公共建築, pp. 147-153, 1997.3

10）神原浩,林康裕，田村和夫：アンタート調查に基づく建物の非粚造部材 被害と地震動強さとの関俰, 日本建筑学会構造系論文集, No.578, pp.155$161,2004.4$

11) 日本建築学会：2003年5月 26 日宫城県沖の地震災害調查報告 2003 年 7 月 26 日宮城県北部の地震災害調查報告, 2004.3

12）日本建筑学会 : 阪神淡路大震災調查報告 建築編-7 建筑計画, pp.52-61, 1999.3

(2004年6月10日原稿受理，2004年 8 月16日採用決定） 